\title{
Rancang Bangun Sistem Pengelolaan Surat Berbasis Web Menggunakan Metode Rapid Application Development Di Biro SDM Badan Narkotika Nasional (BNN)
}

\author{
Ega Aryan Sentosa ${ }^{1}$, Septi Andryana ${ }^{2}$, Aris Gunaryati ${ }^{3}$ \\ ${ }^{1,2,3}$ Informatika, Fakultas Teknologi Komunikasi dan Informatika Universitas Nasional \\ Jl. Sawo Manila, Pejaten Ps. Minggu Jakarta 12520 \\ e-mail: 1egaaryans@gmail.com, ${ }^{2}$ septi.andryana@civitas.unas.ac.id, \\ aris.gunaryati@civitas.unas.ac.id
}

\begin{abstract}
Abstrak
Pengelolaan surat menyurat secara digital merupakan salah satu terobosan yang menguntungkan bagi suatu institusi atau organisasi untuk menjaga agar surat yang diterima di dalam lingkup institusi atau organisasi tersebut tetap tertata dan terdata dengan baik. Biro SDM BNN merupakan salah satu biro di BNN yang menerima banyak surat maupun undangan kedinasan hampir setiap hari. Pencatatan yang masih bersifat manual di Biro SDM BNN membuat proses surat menyurat menjadi kurang efektif dari segi waktu dan resiko adanya surat yang hilang, rusak atau tercecer. Penelitian ini bertujuan untuk merancang sistem pengelolaan surat digital berbasis web di Biro SDM BNN. Sistem yang dibuat akan dijalankan di jaringan lokal Biro SDM BNN sehingga dapat menambahkan, menyimpan, menghapus, mencari berdasarkan tanggal dan melakukan disposisi surat. Sistem ini dirancang dengan menggunakan metode Rapid Application Development (RAD) dengan bahasa pemrograman PHP, MySQL sebagai database serta menggunakan XAMPP sebagai server lokal. Hasil penelitian ini menunjukkan sistem informasi yang dibuat dapat mengelola surat masuk, mendisposisikan surat dan menyimpan surat dalam database sistem. Dengan demikian diharapkan semua data surat yang diterima dapat dikelola dengan lebih maksimal.
\end{abstract}

Kata kunci-My SQL, PHP, Rapid Application Development, Surat Menyurat, XAMPP.

\begin{abstract}
Digital correspondence management system is one of the major breakthrough that is beneficial for an institution or an organization to ensure that every correspondence-related activities are well-organized and registered properly. The SDM of BNN bureau is one of the bureaus in BNN that receives many letters and official invitations almost on a daily basis. The manual record-keeping method that is still applied by BNN result in a less-effective correspondence, given that it is more time-consuming and that there might be chances of the letters being misplaced or scattered all over the place. This research mainly aims to develop a web-based digital correspondence management system specifically in the SDM of BNN bureau. The aforementioned system is expected to be operated on BNN's local network in order that they can add, save, delete and search the letter that they need by date, as well as making letter disposition much easier. This system is developed by using Rapid Application Development (commonly known as RAD) method with PHP programming language, MySQL database, along with XAMPP as the local server. The result shows the system could organize the letters, making letter disposistion and also can save all the letters in database system. Thus, it is very much expected that all the letters could be more organized in the future.
\end{abstract}

Keywords-MySQL, PHP, Rapid Application Development, Correspondence Letter, XAMPP. 


\section{PENDAHULUAN}

$\mathrm{K}_{\mathrm{n}}^{\mathrm{e}}$ egiatan surat menyurat adalah hal yang penting di dalam suatu instansi. Setiap data surat masuk maupun data surat keluar perlu dipastikan tersimpan dan tertata dengan baik [1]. Saat ini, masih terbilang banyak instansi atau organisasi yang melakukan pengelolaan surat secara manual dimana surat yang diterima dicatat manual ke dalam buku sehingga bilamana catatan tersebut hilang, tercecer maupun rusak maka data surat akan hilang [2].

Biro SDM BNN merupakan satuan kerja di bawah naungan Sekretariat Umum BNN yang sangat berperan penting dalam berbagai kegiatan internal maupun eksternal BNN. Oleh karenanya, Biro SDM dapat menerima banyak surat maupun undangan kedinasan hampir setiap hari dan tak sedikit diantaranya yang perlu didisposisikan. Namun hingga saat ini pencatatan surat yang diterima masih dilakukan secara manual oleh resepsionis begitupula dengan proses disposisi surat yang masih manual dalam bentuk surat fisik. Hal ini tentunya membuat proses pengelolaan surat menyurat menjadi kurang efektif dari segi waktu maupun tingginya resiko surat hilang, rusak atau tercecer [3]. Pada proses disposisi surat juga tentunya dapat mengalami kendala seperti keterlambatan dalam proses penyampaian informasi akibat pimpinan yang tidak berada di tempat maupun surat yang hilang hingga tidak dapat didisposisikan [4].

Penelitian Wafa dan Nana (2020) mengenai rancang bangun sistem informasi manajemen surat di BPJS Sukabumi dapat ditarik kesimpulan bahwa sistem yang telah dibuat dapat mempermudah pegawai Kantor BPJS Sukabumi dalam melakukan pengarsipan surat [5].

Dalam proses pengembangan sistem yang berbasis internet dapat menggunakan berbagai metode, salah satunya ialah Metode Rapid Application Development. RAD adalah metode untuk pengembangan perangkat lunak secara bertingkat. Metode RAD berpusat pada pembangunan yang lebih singkat dan cepat namun dengan hasil kualitas yang lebih tinggi dibandingkan metode yang lainnya [6]. Dalam proses pengembangan sistem, metode RAD menggunakan metode pengulangan dimana working model sistem dibuat pada tahap awal pengembangan untuk menetapkan kebutuhan pengguna [7].

Penelitian Ariyanti (2018) menjelaskan tentang struktur dan tahapan dasar RAD yang terdiri dari 3 yaitu: Requirements Planning, Design Workshop, dan Implementation [8]. Kemudian Elyana, dkk. (2019) dan Wishnu, dkk (2020) juga memilih menggunakan metode RAD dalam pembuatan sistem informasi manajemen surat, kedua penelitian ini memberikan hasil bahwa sistem informasi yang dibuat sangat membantu dalam pengelolaan surat di suatu institusi atau organisasi serta penggunaan metode RAD mempermudah dalam proses pembuatan sistem karena membutuhkan waktu yang relative singkat [9],[10]. Penelitian - penelitian di atas inilah yang kemudian dijadikan acuan dalam pengembangan sistem nantinya.

Melihat permasalahan yang muncul di atas, maka diperlukan rancangan sistem untuk melakukan pengelolaan surat menyurat yang dapat melakukan pendataan setiap surat yang diterima, melakukan pencarian surat serta mempermudah proses disposisi surat sehingga dapat meningkatkan efisiensi kerja dengan menggunakan metode RAD.

\section{METODE PENELITIAN}

\subsection{Objek Penelitian}

Objek penelitian penulis berlokasi di Biro SDM di Badan Narkotika Nasional Jakarta.

\subsection{Teknik Pengumpulan dan Jenis Data}

Pengumpulan data ini dilakukan melalui pengamatan dan wawancara kepada pihak terkait

Ega, et., al [Rancang Bangun Sistem Pengelolaan Surat Berbasis Web Menggunakan Metode Rapid Application Development Di Biro SDM Badan Narkotika Nasional (BNN) 
serta melakukan studi literature. Sementara untuk jenis data yang digunakan adalah data informasi yakni data yang mencakup proses pengelolaan surat menyurat di Biro SDM BNN.

\subsection{Desain Penelitian}

Untuk tahapan proses penelitian dapat dilihat adalah sebagai berikut:

1) Melakukan analisis dengan cara:

a. Observasi, yaitu mengamati secara langsung proses pengelolaan surat yang sedang terjadi.

b. Wawancara, yaitu melakukan tanya jawab dengan narasumber terkait informasi yang nantinya dapat digunakan untuk pemecahan masalah.

c. Studi literature, yaitu mempelajari landasan teori untuk menemukan solusi.

2) Melakukan desain sistem, yaitu pembuatan rancangan sistem informasi surat berbasis web sesuai dengan kebutuhan Biro SDM BNN.

3) Membuat program, yaitu membuat program dari hasil rancangan sistem berbasis web.

4) Melakukan testing yaitu mengimplementasikan program yang telah dibuat dan melakukan revisi apabila ditemui ketidaksesuaian.

\subsection{Rapid Application Development (RAD)}

Rapid Application Development (RAD) adalah strategi untuk menyediakan mengembangkan sistem supaya lebih efektif dengan kualitas yang lebih baik dibandingkan dengan metode lain. Metode RAD terdiri dari 3 fase yakni:

1) Requirement Planning, fase untuk membahas mengenai tujuan aplikasi atau sistem.

2) RAD Design Workshop, fase ini untuk merancang dan memperbaiki program atau sistem.

3) Implementation, fase dimana sistem yang telah dibuat dan disetujui akan diujicoba dan diperkenalkan [10].

\section{HASIL DAN PEMBAHASAN}

Berdasarkan hasil observasi dan wawancara beberapa pegawai di bagian Biro Kepegawaian di BNN Jakarta diperoleh data bahwa proses disposisi surat masih dilakukan secara manual sehingga menyebabkan adanya surat yang menumpuk dan waktu yang diperlukan untuk melakukan disposisi suatu surat membutuhkan waktu yang cukup lama. Surat yang masuk masih dicatat secara manual oleh resepsionis dan baru dapat diproses apabila Kepala Biro berada di tempat. Proses untuk surat dari Kepala Biro pun memakan waktu yang cukup lama sampai surat dapat didisposisi.

\subsection{Skema Database}

Perancangan sistem ini menggunakan XAMPP sebagai localhost dan MySQL sebagai database. Tabel yang digunakan diantaranya tabel bagian untuk menyatakan jabatan user, tabel lampiran untuk menyatakan semua surat yang masuk maupun yang sedang diproses dan yang sudah selesai didisposisikan, tabel memo untuk menyimpan semua memo yang ada, tabel nomor surat menyatakan semua nomor surat yang masuk maupun yang keluar, tabel surat masuk menyimpan semua surat masuk, tabel surat keluar menyimpan semua surat keluar, dan tabel user untuk menyimpan data pengguna.

Ega, et., al [Rancang Bangun Sistem Pengelolaan Surat Berbasis Web Menggunakan Metode Rapid Application Development Di Biro SDM Badan Narkotika Nasional (BNN) 


\subsection{Use Case Diagram}

Use case diagram adalah pemodelan kelakuan sistem informasi yang akan dibuat. Use case diagram berguna untuk mendeskripsikan pola interaksi antar user dengan sistem [11]. Use case menggambarkan bagaimana sistem tersebut dipakai. Gambar 1 menujukkan use case diagram sistem pengelolaan surat di BNN.

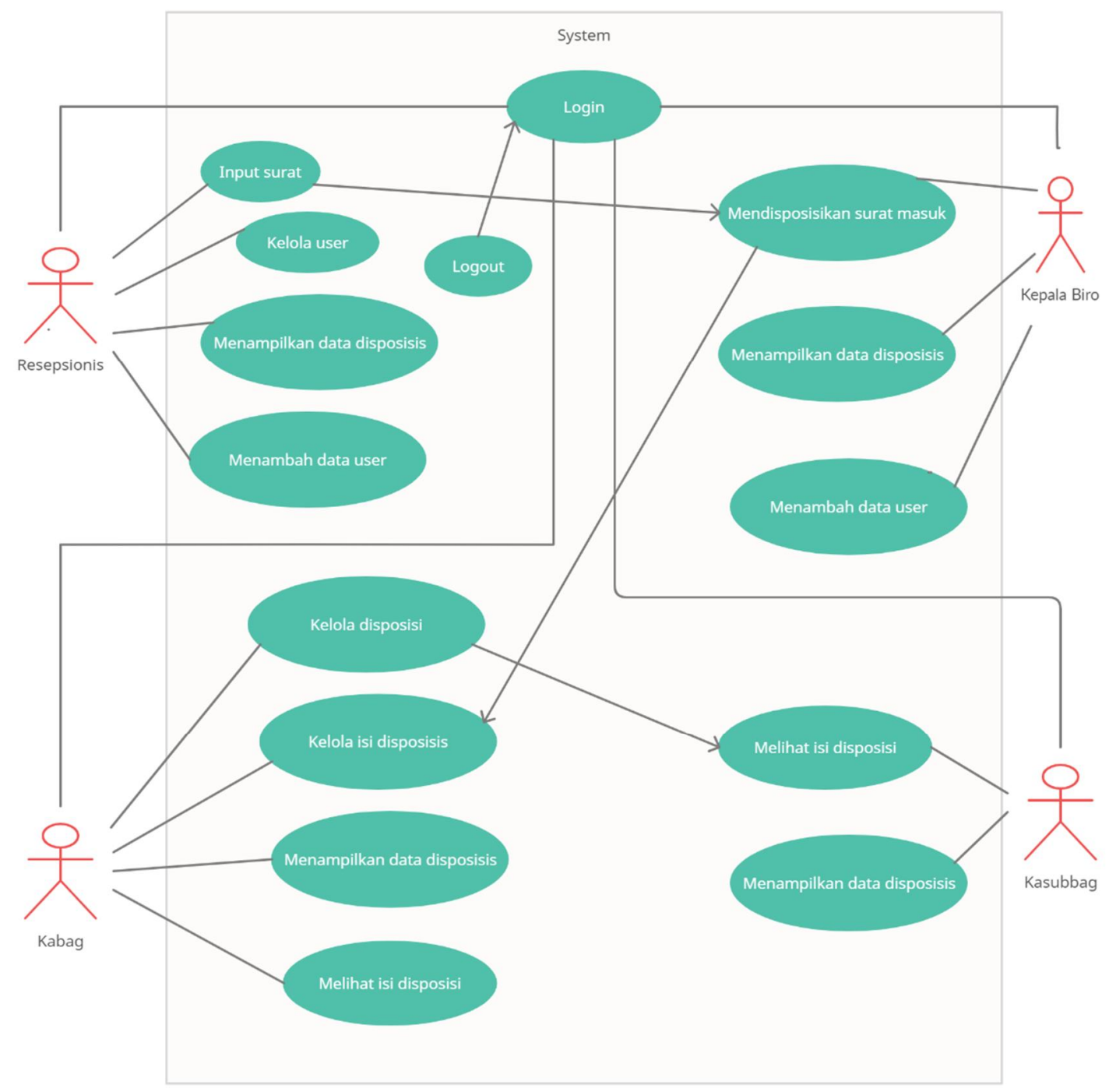

Gambar 1. Use Case Diagram

Ega, et., al [Rancang Bangun Sistem Pengelolaan Surat Berbasis Web Menggunakan Metode Rapid Application Development Di Biro SDM Badan Narkotika Nasional (BNN) 


\subsection{Activity Diagram}

Activity diagram menunjukkan aktivitas dari sistem yang ada pada perangkat lunak [11]. Activity diagram sistem pengelolaan surat di BNN lihat Gambar 2.

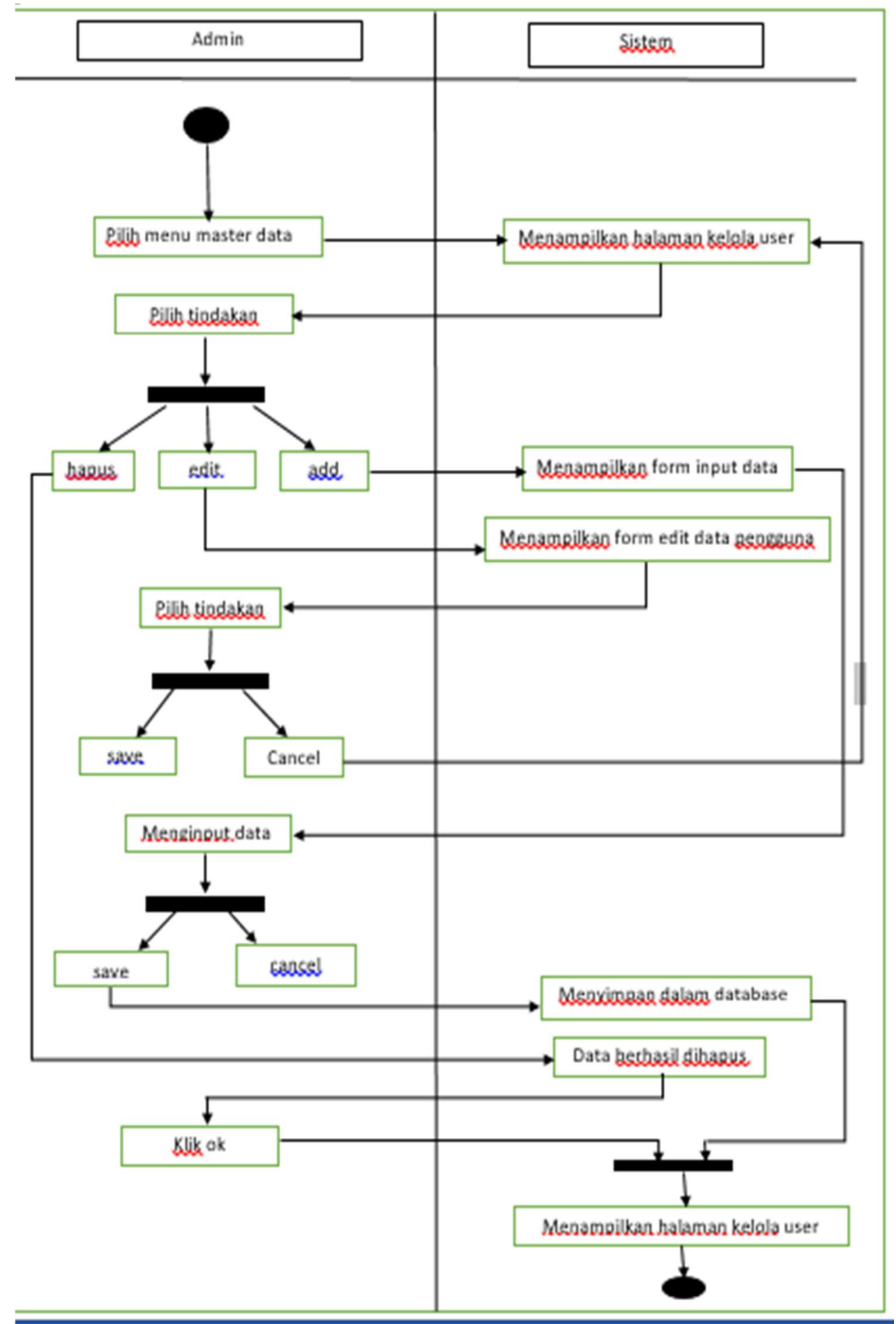

Gambar 2. Activity Diagram

Ega, et., al [Rancang Bangun Sistem Pengelolaan Surat Berbasis Web Menggunakan Metode Rapid Application Development Di Biro SDM Badan Narkotika Nasional (BNN) 


\subsection{Implementasi}

Sistem ini dijalankan pada jaringan lokal pengguna di Biro SDM BNN yang dapat diakses oleh user lewat web browser kemudian mengetikkan pada kolom url web browser untuk masuk ke halaman login. Sistem ini dapat diakses oleh resepsionis, kepala Biro, Kepala Bagian dan Kepala Subbagian di Biro SDM BNN.

\subsubsection{Halaman Login}

Halaman login (Gambar 3) dapat diakses oleh semua user yakni resepsionis, kepala Biro, Kepala Bagian dan Kepala Subbagian. Pada menu login ini terdapat box untuk mengisi nama pengguna dan kata sandi.

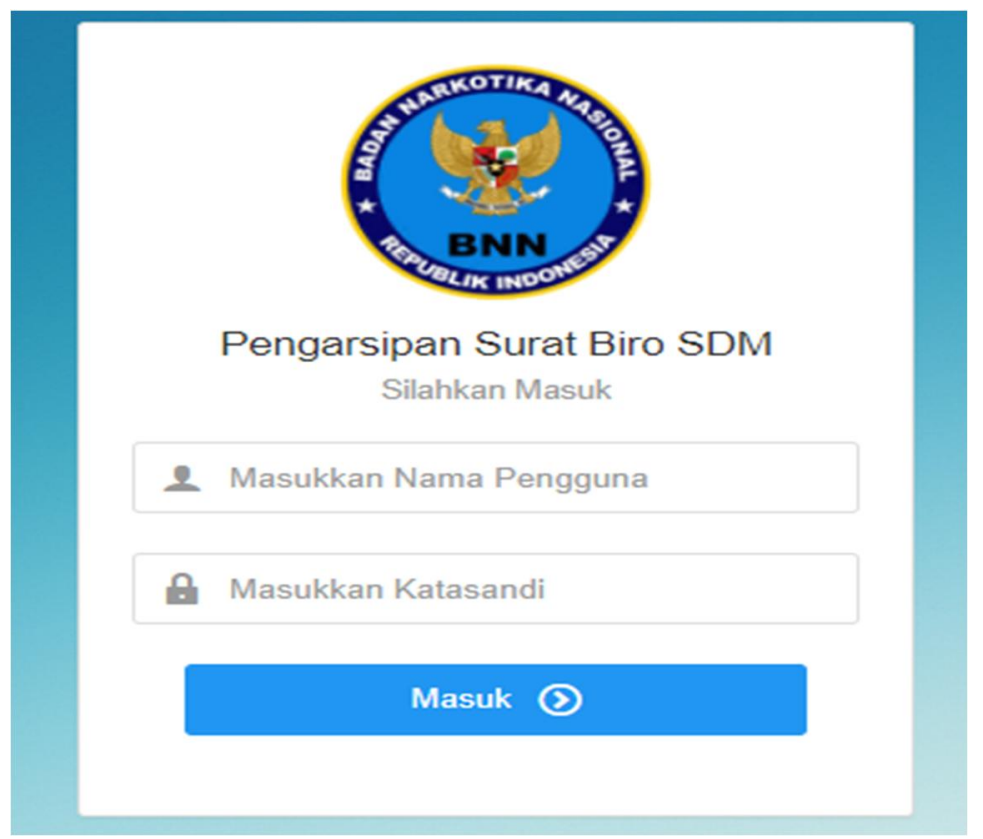

Gambar 3. Halaman Login

\subsubsection{Halaman Utama}

Setelah login menggunakan username dan password yang sesuai, user akan dialihkan ke halaman utama.

Halaman utama pada sistem informasi ini terdapat menu Beranda yang menampilkan halaman utama, Master Data yang menampilkan data pengguna dan jabatan, Data Surat yang menampilkan surat masuk dan surat keluar (terdiposisi), Pelaporan yang menampilkan pendataan tentang semua surat yang telah diterima dan terdiposisi. Logout untuk kembali ke menu login, box Surat Masuk menyatakan jumlah surat masuk yang diterima, box Surat Keluar menyatakan jumlah surat yang keluar (terdisposisi), Kalender yang menampilkan bulan berjalan dan Nama Pengguna untuk melihat profile pengguna.

Pada bagian halaman utama ini secara keseluruhan hampir sama namun terdapat beberapa perbedaan antar pengguna, misalnya untuk resepsionis tidak terdapat tampilan box surat masuk (dapat dilihat di Gambar 4), 


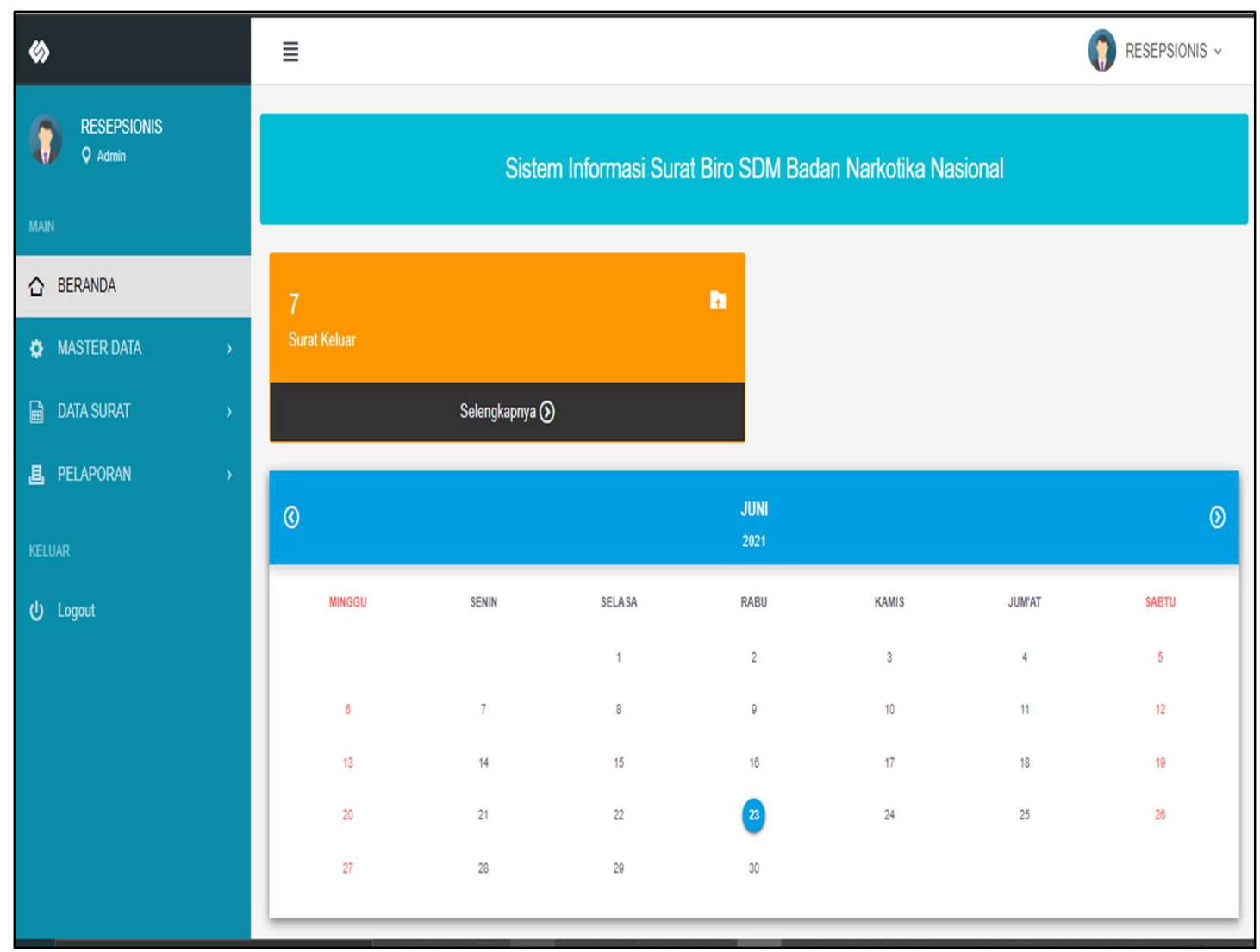

Gambar 4. Halaman Utama Resepsionis

sementara Kepala Biro dan Kepala Bagian memiliki box surat masuk dan surat keluar (dapat dilihat di Gambar 5 dan Gambar 6). 


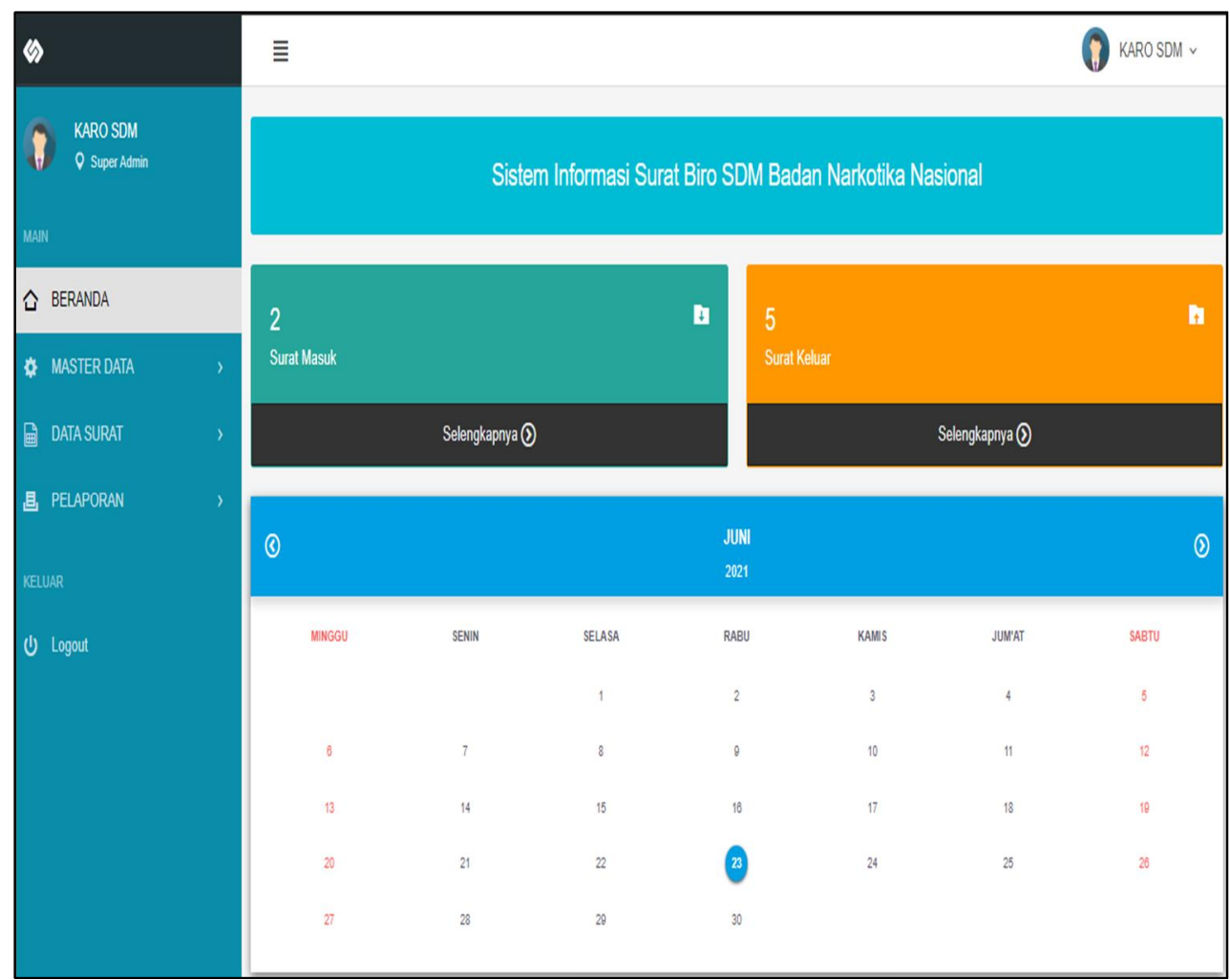

Gambar 5. Halaman Utama Kepala Biro SDM

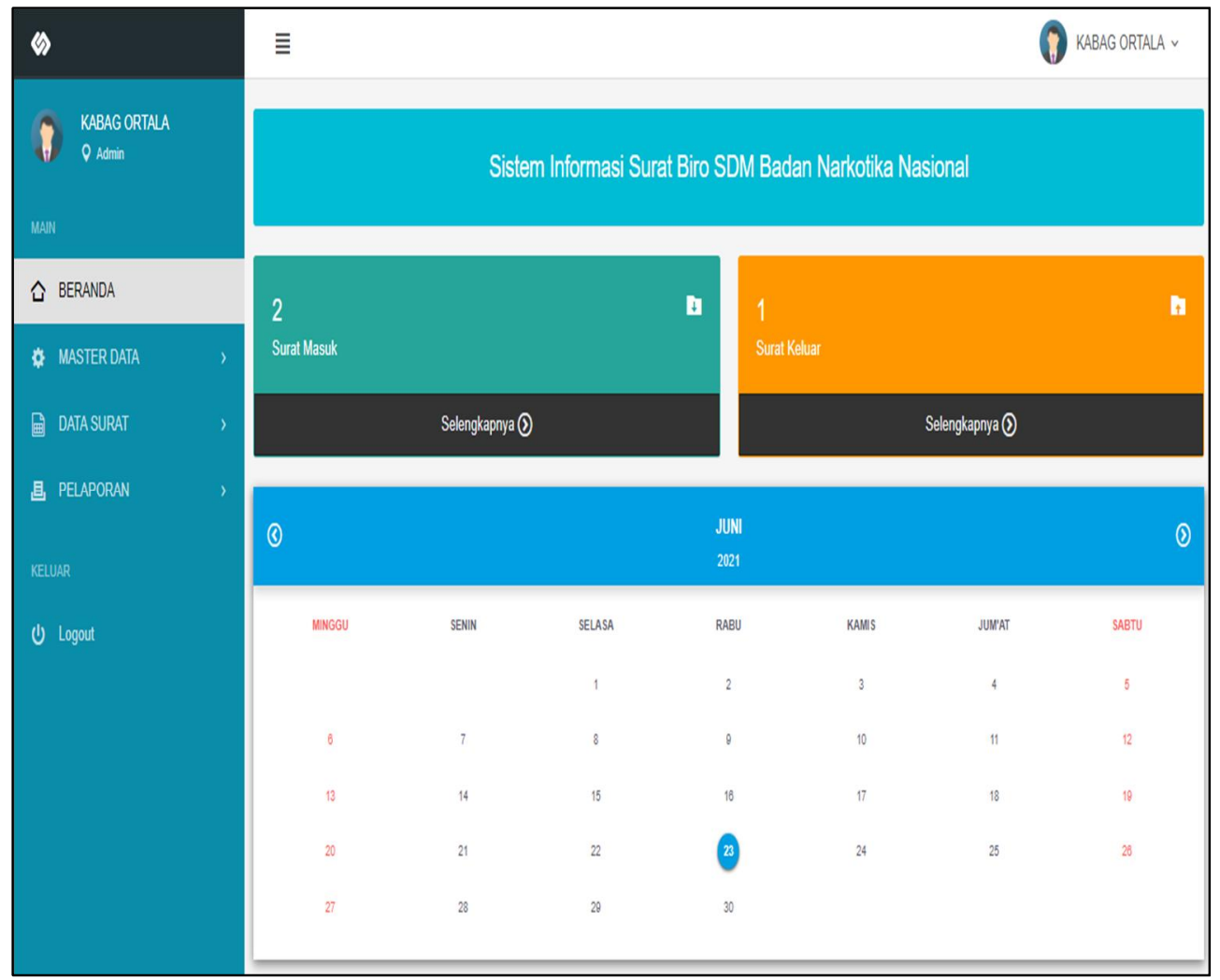

Gambar 6. Halaman Utama Kepala Bagian

Ega, et., al [Rancang Bangun Sistem Pengelolaan Surat Berbasis Web Menggunakan Metode Rapid Application Development Di Biro SDM Badan Narkotika Nasional (BNN) 
disisi lain Kepala Subbagian hanya memiliki box surat masuk saja tanpa box surat keluar (Gambar 7).

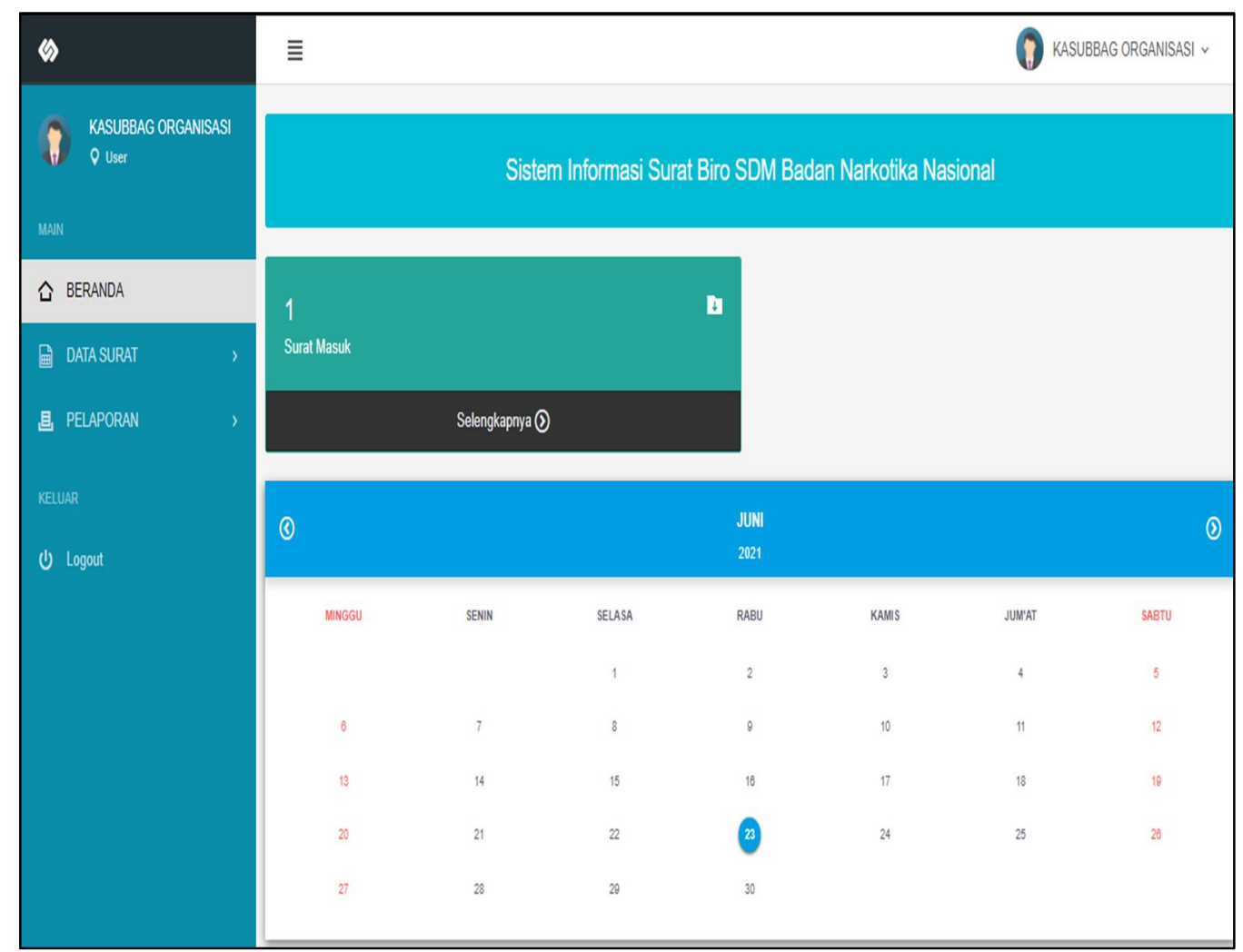

Gambar 7. Halaman Utama Kepala Subbagian

Hal ini disesuaikan dengan fungsi dari tiap jabatan dalam melakukan disposisi surat dimana resepsionis berfungsi untuk menginput surat masuk, Kepala Biro dan Kepala Bagian berfungsi untuk melakukan disposisi surat sedangkan Kepala Subbagian berfungsi sebagai penerima disposisi terakhir sehingga tidak dapat medisposisikan surat.

\subsubsection{Halaman Master Data}

Pada menu Master Data terdapat dua menu yaitu User yang menampilkan pengguna sistem informasi ini. Untuk menambahkan, mengedit atau mengurangi user dapat dilakukan oleh Resepsionis dan Kepala Biro. Selain itu terdapat menu Bagian yang menampilkan jabatan dan bagian yang ada di Biro SDM BNN. Tampilan halaman menu User dapat dilihat pada Gambar 8 dan menu Bagian pada Gambar 9. 


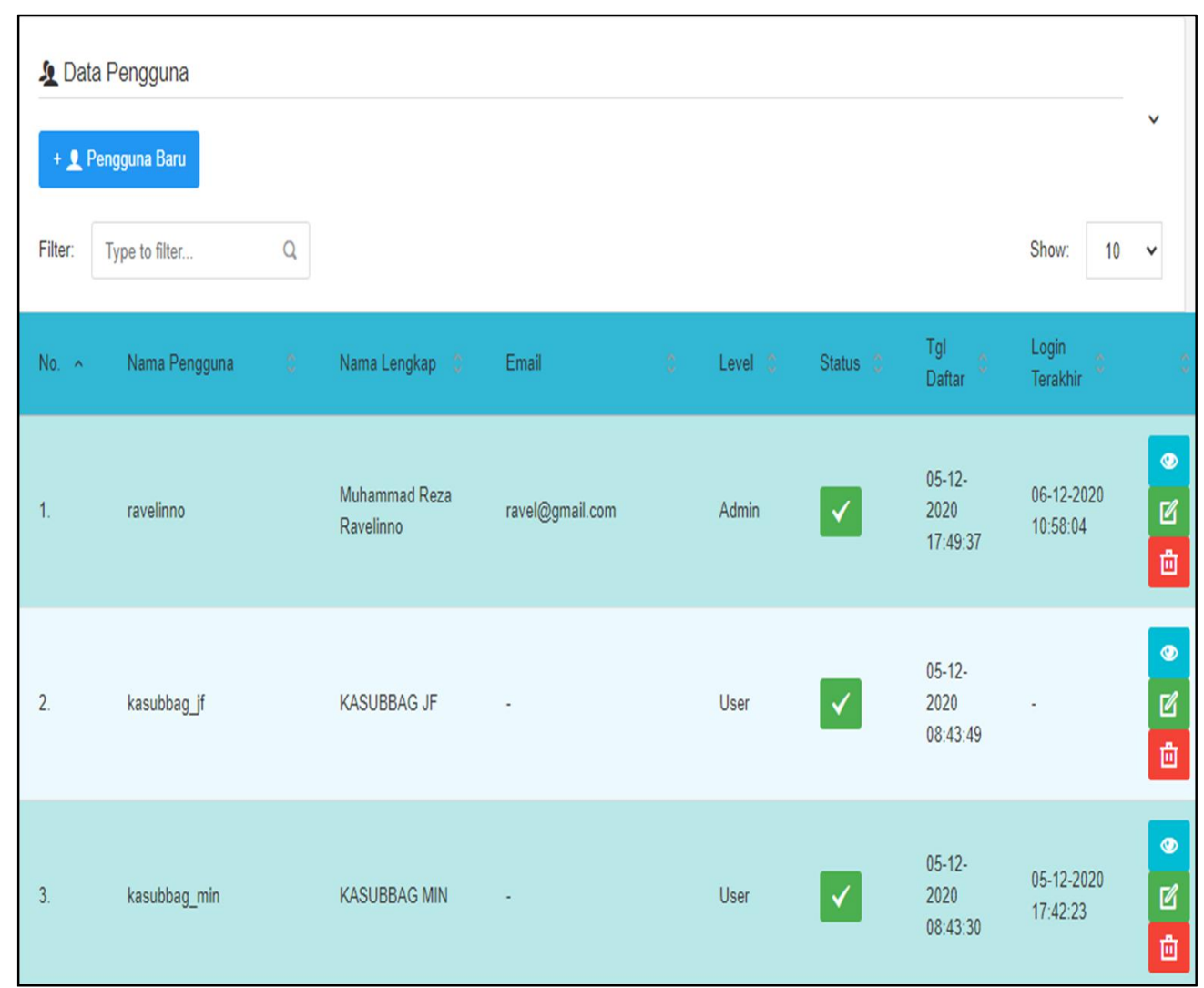

Gambar 8. Halaman Data User

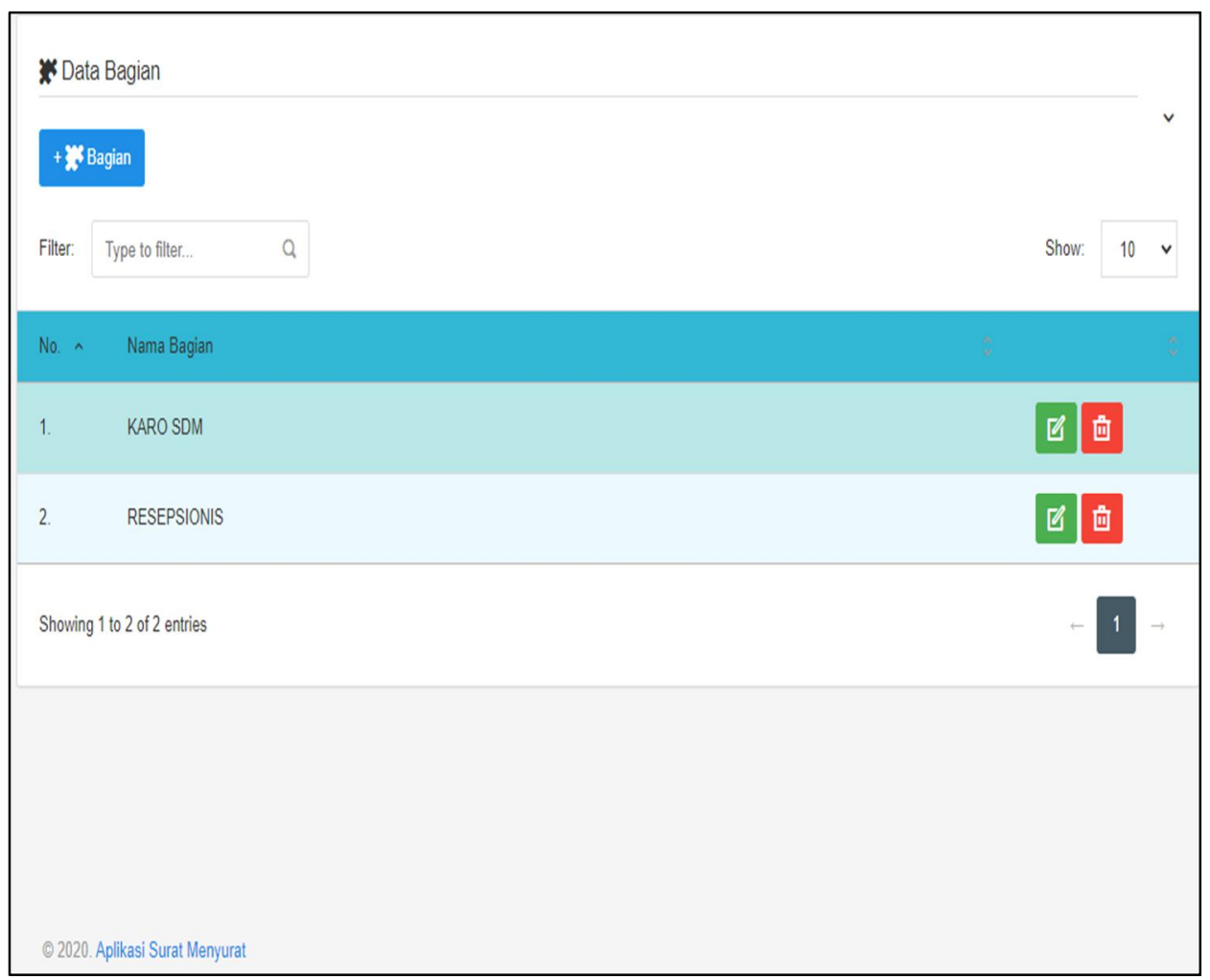

Gambar 9. Halaman Data Bagian

Ega, et., al [Rancang Bangun Sistem Pengelolaan Surat Berbasis Web Menggunakan Metode Rapid Application Development Di Biro SDM Badan Narkotika Nasional (BNN) 


\subsubsection{Halaman Data Surat}

Pada halaman Data Surat terdapat dua menu yakni Surat Masuk dan Surat Keluar. Setiap surat masuk yang di input oleh Resepsionis akan masuk ke menu Surat Masuk dan akan diberikan nomor surat secara otomatis oleh sistem secara berurutan. Sementara setiap surat yang didisposisi akan masuk ke menu Surat Keluar. Hal ini bertujuan untuk mempermudah proses pencarian surat apabila diperlukan.

\section{Surat Masuk}

Menu Surat Masuk terdiri dari menu Nomor, Nomor Surat, Perihal yang berisi hal atau keterangan isi surat, Pengirim, Penerima, Dibaca yang menampilkan tanda ceklis bila surat sudah dibaca oleh penerima dan Aksi yang berisi 3 langkah yang dapat dipilih yakni melihat isi surat yang disimbolkan dengan ikon $\odot$, mendisposisikan surat yang disimbolkan dengan ikon 医 dan ikon 目 untuk menghapus surat. Tampilan Data Surat Masuk dapat dilihat pada Gambar 10.

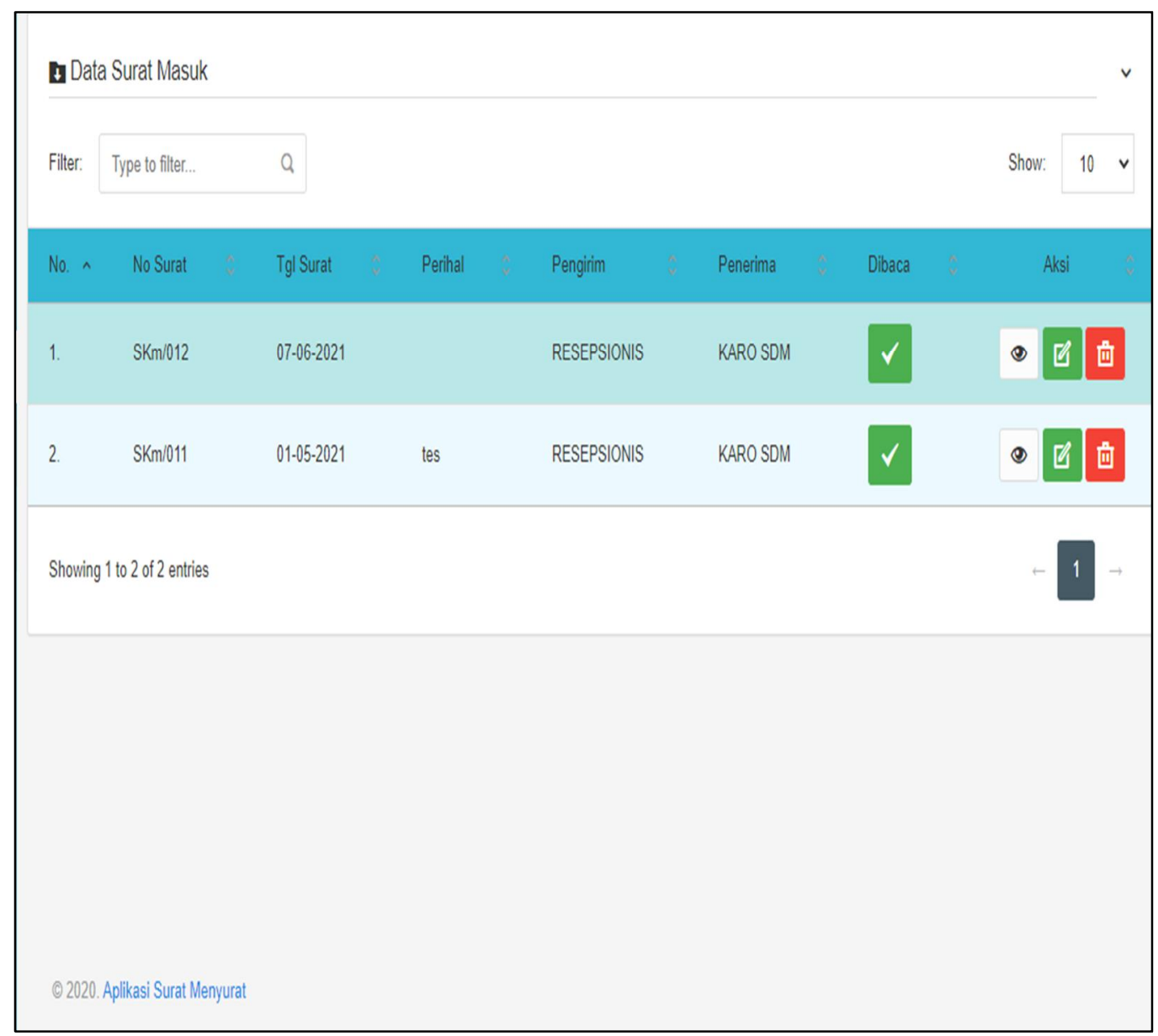

Gambar 10. Halaman Data Surat Masuk

Saat memilih menu $\odot$ pengguna akan dialihkan ketampilan seperti pada Gambar 11. Dalam menu ini terdapat No. Asal yakni nomor surat, kemudian Tanggal yang menunjukkan

Ega, et., al [Rancang Bangun Sistem Pengelolaan Surat Berbasis Web Menggunakan Metode Rapid Application Development Di Biro SDM Badan Narkotika Nasional (BNN) 
tanggal surat di input, Pengirim, Penerima, Perihal dan Lampiran yang berisi berkas surat yang dapat di download.

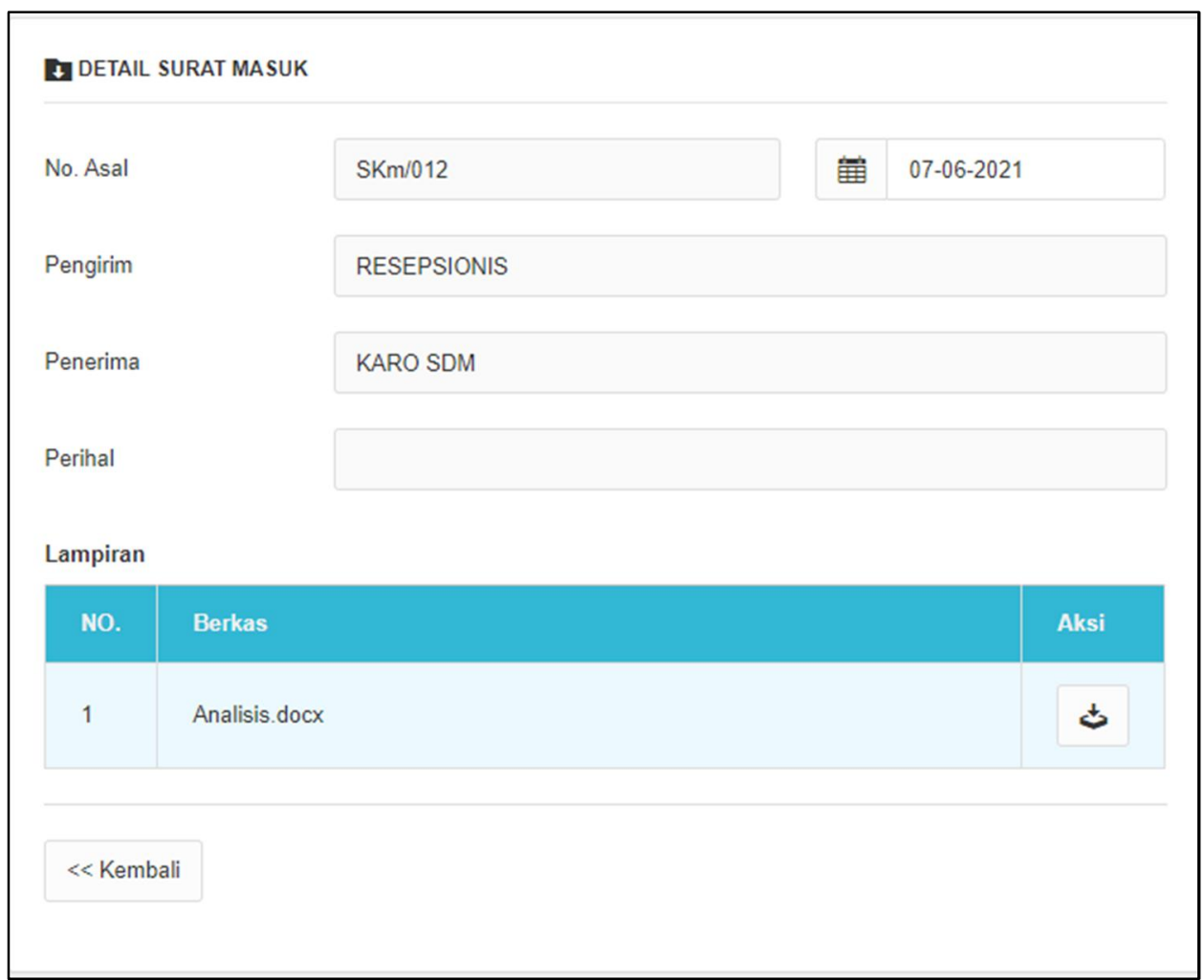

Gambar 11. Detail Surat Masuk

Saat memilih ikon $\mathbb{6}$ pengguna akan dialihan ke tampilan pada Gambar 12 untuk melakukan disposisi surat, menu ini hanya dapat diakses oleh Kepala Biro dan Kepala Bagian. Dalam menu ini terdapat pilihan No. Surat yaitu nomor surat yang akan didisposisikan, Tanggal Surat, Penerima, Perihal Surat dan Lampiran yang berisi surat yang akan didisposisikan serta pilihan Update untuk mengirim disposisi surat kepada penerima. 
DISPOSISI SURAT

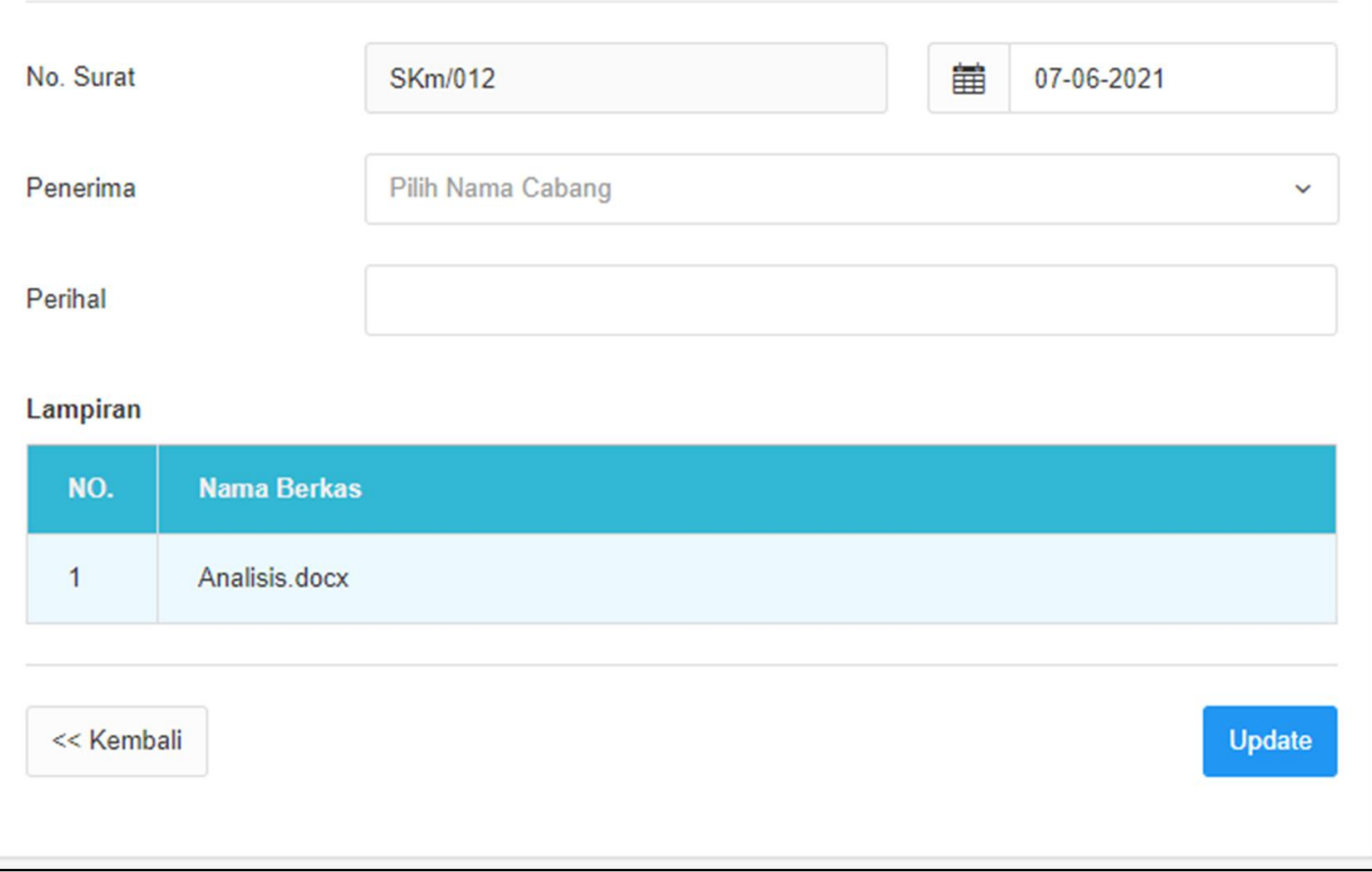

Gambar 12. Tampilan Menu Disposisi Surat

\section{Surat Keluar}

Menu Surat Keluar merupakan menu yang berisi surat yang telah didisposisikan. Menu ini memiliki beberapa komponen yang sama dengan menu Surat Masuk yang membedakannya ialah pada menu Surat Keluar tidak terdapat komponen Pengirim dan pada komponen aksi

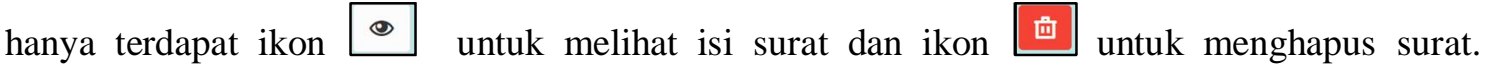
Tampilan Data Surat Keluar dapat dilihat di Gambar 13. 


\begin{tabular}{|c|c|c|c|c|c|c|c|c|}
\hline \multicolumn{8}{|c|}{ b Data Surat Keluar } & \multirow{2}{*}{$\checkmark$} \\
\hline \multicolumn{8}{|c|}{$+\mp$ Buat Surat Baru } & \\
\hline Filter: & Type to filter... & $Q$ & & & & Show: & 10 & $\checkmark$ \\
\hline No. ^ & Nomor & Tanggal & Perihal & Penerima & Dibaca & \multicolumn{3}{|c|}{ Detail } \\
\hline 1 & $\mathrm{SKm} / 006$ & $07-12-2020$ & percobaan fitur baru web & KABAG RENMIN & $\checkmark$ & (1) & 它 & \\
\hline 2 & SKm/003 & $05-12-2020$ & penetapan jabatan baru & KASUBBAG ORGANISASI & $\checkmark$ & (1) & id & \\
\hline 3 & SKm/004 & $05-12-2020$ & acara dinas & KABAG ORTALA & $\checkmark$ & e) & & \\
\hline 4 & SKm/005 & $05-12-2020$ & test pembaca & KASUBBAG MIN & $\checkmark$ & () & & \\
\hline 5 & SKm/009 & 01-05-2021 & undangan & KABAG ORTALA & $\checkmark$ & (1) & 宁 & \\
\hline 6 & SKm/012 & $07-06-2021$ & & KARO SDM & $\checkmark$ & (1) & i़ & \\
\hline
\end{tabular}

Gambar 13. Tampilan Menu Surat Keluar

\subsubsection{Halaman Pelaporan Surat}

Menu Pelaporan Surat merupakan menu untuk menunjukkan rekapan semua data surat yang masuk pada kurun waktu tertentu dengan periode yang dapat dipilih maksimal satu bulan. Menu Pelaporan Surat ini dilengkapi dengan kemampuan untuk mencetak hasil dari rekapan surat apabila diperlukan. Tampilan awal menu Pelaporan Surat dapat dilihat pada Gambar 14 dan tampilan setelah memilih periode waktu yang diingikan ditunjukkan pada Gambar 15.

\section{GLPPORAN SURAT MASUK}

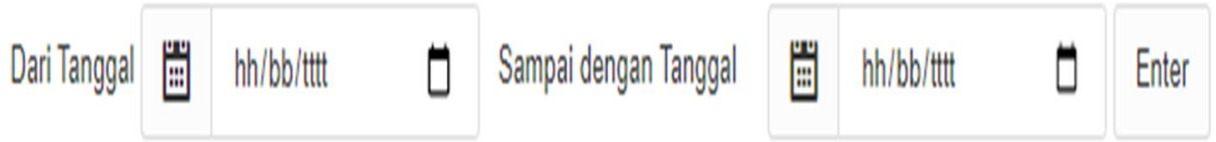

Gambar 14. Tampilan Awal Menu Pelaporan Surat

Ega, et., al [Rancang Bangun Sistem Pengelolaan Surat Berbasis Web Menggunakan Metode Rapid Application Development Di Biro SDM Badan Narkotika Nasional (BNN) 


\begin{tabular}{|c|c|c|c|c|c|c|}
\hline \multicolumn{7}{|c|}{ Data Laporan Surat Masuk } \\
\hline \multicolumn{7}{|c|}{ Cetak Laporan } \\
\hline Filter: & Type to filter... & Q & & & Show: & $0 v$ \\
\hline No $\wedge$ & Tanggal & No. Surat & Perhal & Penerima & Dibaca & \\
\hline 1 & $07.06-2021$ & SKm/012 & & KARO SDM & $\checkmark$ & \\
\hline \multicolumn{4}{|c|}{ Showing 1 to 1 of 1 entries } & & $\leftarrow$ & $\rightarrow$ \\
\hline
\end{tabular}

Gambar 15. Tampilan Data Laporan Surat Masuk

\subsubsection{Halaman Profile Pengguna}

Halaman Profile Pengguna berisi hal yang berkaitan dengan data pengguna seperti Nama Pengguna atau username, Nama Lengkap, Email Pengguna, Level yang menjelaskan posisi pengguna dalam sistem, Alamat Pengguna, Telepon, Pengalaman. Menu ini juga disertai dengan informasi tanggal pengguna didaftarkan pertama kali, waktu login terakhir serta dilengkapi dengan fitur untuk mengubah password. Tampilan halaman Profile Pengguna dapat dilihat pada Gambar 16.

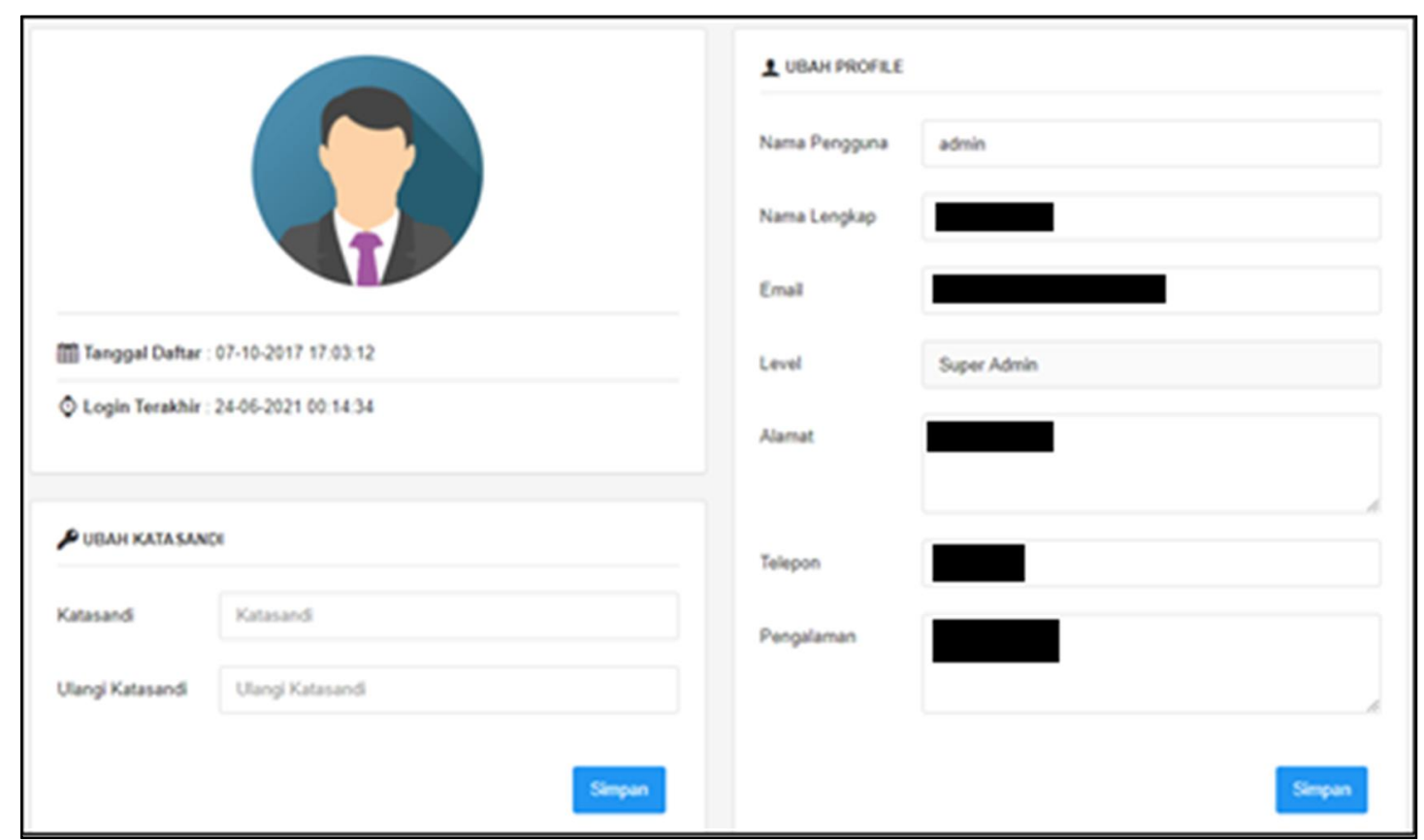

Gambar 16. Tampilan Halaman Profile Pengguna

Ega, et., al [Rancang Bangun Sistem Pengelolaan Surat Berbasis Web Menggunakan Metode Rapid Application Development Di Biro SDM Badan Narkotika Nasional (BNN) 


\section{KESIMPULAN}

Berdasarkan penelitian yang telah dilakukan pada Biro SDM Badan Narkotika Nasional dapat disimpulkan bahwa melalui sistem informasi pengelolaan surat yang telah dibuat maka pencatatan surat secara manual di Biro SDM BNN dapat dihilangkan diganti dengan sistem terintegrasi dan terkomputerisasi sehingga dapat meningkatkan efektivitas dan efisiensi dalam bekerja terutama di bidang administrasi. Sistem ini dapat memudahkan pegawai dalam melakukan pencarian surat, disposisi surat, membuat laporan surat yang diterima serta meminimalisir surat yang tidak terproses karena hilang, rusak atau tercecer. Pemilihan metode Rapid Application Development dalam pengembangan sistem informasi membuat sistem dapat dibuat dengan lebih cepat dengan kualiatas yang lebih baik

\section{SARAN}

Untuk penelitian selanjutnya diharapkan dapat mengembangkan sistem ini agar dapat dilengkapi dengan notifikasi sehingga memudahkan user untuk menindaklanjuti surat yang masuk.

\section{DAFTAR PUSTAKA}

[1] E. Sugiharti dan S. E. Triliani. 2015, "Perancangan Aplikasi Surat Masuk dan Keluar pada PT. Angkasa Pura 1 Semarang, Scientific Journal of Informatics, Vol. 1, No. 1, pp $39-52$.

[2] Saputra, K. A., \& Famukhit, M. L. 2014, "Perancangan Sistem Informasi Pengelolaan Surat Masuk dan Surat Keluar pada MTs Guppi Jetiskidul," IJNS - Indonesian Journal on Networking and Security, Vol. 3, No. 4.

[3] D. A. Priyadi, dan E. W. Lestari. 2018, "Perancangan Sistem Informasi Pelayanan Surat Menyurat pada Kantor Desa Tanjungsari Kutowinangun Kebumen Berbasis Desktop, Jurnal Teknik Komputer, Vol. 4, No.2, pp 84-91.

[4] R. Diajeng dan K. Nia dan S. Yuni. 2018, "Sistem Informasi Disposisi Surat Berbasis Android," Applied Information System and Management (AISM), Vol. 1, No. 1, pp 45 50 .

[5] P. Wafa dan S. Nana. 2020. "Rancang Bangun Sistem Informasi Manajemen Surat Berbasis Web pada Kantor BPJS Ketenagakerjaan Cabang Sukabumi,” Ensains, Vol. 3, No. 1.

[6] A.K Nalendra. 2021, "Rapid Aplication Development (RAD) Model Method for Creating an Agricultural Irrigation System Based on Internet of Things", IOP Conference Series: Material Science and Engineering, pp $1-6$.

[7] N. Aini dan S. A. Wicaksono dan I. Arwani. 2019, "Pembangunan Sistem Informasi Perpustakaan Berbasis Web Menggunakan Metode Rapid Application Development (RAD) (Studi pada: SMK Negeri 11 Malang)," Jurnal Pengembangan Teknologi Informasi dan Ilmu Komputer, Vol. 3, No. 9. 
[8] I. Ariyanti. 2018, "Pengembangan Sistem Informasi Perpustakaan Sekolah Dengan Rapid Application Development, ”Jurnal Pilar Nusa Mandiri, Vol. 14, No. 1, pp. 55 - 60.

[9] I. Elyana, I. Kholil, F.E. Schaduw. 2019, "Rancang Bangun Sistem Informasi Manajemen Surat Menyurat Dengan Menggunakan Metode RAD (Rapid Application Development),” Jurnal Riset Informatika, Vol. 1, No. 2, pp 107 - 112.

[10] P. A. Wishnu dan S. I. Lili dan S. Sujono. 2020, "Rancangan Bangun Sistem Berbasis Web Pengarsipan Surat pada Kesekertariatan KONI Provinsi Kep. Bangka Belitung," Jurnal IT CIDA, Vol. 6, No. 2, pp 10 - 24.

[11] P. Sega dan S. Sigit Muhamad. 2017, "Sistem informasi Pengelolaan Surat Menyurat di Direktorat Pengamanan BP Batam Berbasis Web," Zona Komputer, Vol. 7, No.3. 